\title{
Granular Cell Tumor of Breast: a Case Report and Review of Literature
}

\author{
Bhargavan Rexeena $^{1}$ • Augustine Paul ${ }^{1} \cdot$ Ranjan Acharya Nitish ${ }^{1} \cdot$ Cherian Kurian $^{1}$. \\ R. K. Anila ${ }^{2}$
}

Received: 17 February 2015 / Accepted: 25 August 2015 / Published online: 2 September 2015

(C) Indian Association of Surgical Oncology 2015

\begin{abstract}
This is an article reporting a case of granular cell tumor in the left breast in a 58 year old lady. Patient presented with a $3 \times 3 \mathrm{~cm}$ mass in the left breast. Mammography reported a BIRADS 5 lesion in the left breast. With a clinical and radiological diagnosis of malignancy, patient was sent for FNAC (Fine needle aspiration Cytology). The cytology report was granular cell tumor. Following this patient underwent wide excision of the mass. Histopathology confirmed the cytological diagnosis of granular cell tumor of the breast. Patient is on regular follow up and is presently free of disease. The case report is followed up by a brief review of literature of granular cell tumor of the breast.
\end{abstract}

Keywords Granular cell tumor $\cdot$ Breast $\cdot$ Excision

\section{Case Report}

A 58 year old multiparous post menopausal lady presented with a history of lump in left breast since the past 3 months. Patient was initially evaluated in a local hospital. FNAC from the left breast lesion done outside was reported as lobular carcinoma of the breast. With this report patient was referred to our centre. On examination patient was ECOG 0. General and systemic examination of the patient was normal. On examination the left breast revealed a well defined firm lump

Ranjan Acharya Nitish

drnitishra05@gmail.com

1 Department of Surgical Oncology, Regional Cancer Centre, Trivandrum, Kerala, India

2 Department of Pathology, Regional Cancer Centre, Trivandrum, Kerala, India measuring $3 \times 3 \mathrm{~cm}$ in the upper inner quadrant without skin or chest wall fixity. No axillary or supraclavicular lymphadenopathy was present. Right breast and axilla were normal. Mammography revealed an irregular BIRADS 5 lesion in the left breast and normal right breast (Fig. 1). The patient underwent FNAC at our centre. The cytology smears showed clusters of cells with moderate to abundant granular eosinophilic cytoplasm and bland vesicular nucleus (Fig. 2) and the cytological diagnosis was granular cell tumor. As our pathologist is very experienced and in keeping with the local protocol we proceeded with a wide excision and frozen section on the basis of a FNAC report without a core biopsy. Frozen section confirmed the cytological diagnosis of granular cell tumor with free margins. The defect was closed primarily. Post operative course in the hospital was uneventful and she was discharged on first post operative day. Histopathology showed granular cell tumor measuring $1.5 \times 2 \times 1.5 \mathrm{~cm}$ with infiltrating margins (Fig. 3). Margins of excision were free. Patient is on regular follow up and is clinically disease free at present.

\section{Review of Literature}

Granular cell tumor (GCT) is a soft tissue neoplasm that originates in the nervous system and arises at virtually any body site, but is mainly found in the skin, oral cavity or digestive tract. Most of them are benign and reportedly malignant cases are rare $(1 \%$ or $2 \%)$ [1]. It was first reported by Abrikossoff by the name of granular cell myoblastoma.and considered to be derived from muscle, due to its localization in tongue and pharynx in the first reported cases [2]. Studies using S100 staining and electron microscopy found that the tumor cells originate in Schwann cells of peripheral nerves [3, 4]. It is also known as Abrikossoff's tumor, Granular cell myoblastoma, Granular cell nerve sheath tumor, and Granular cell 


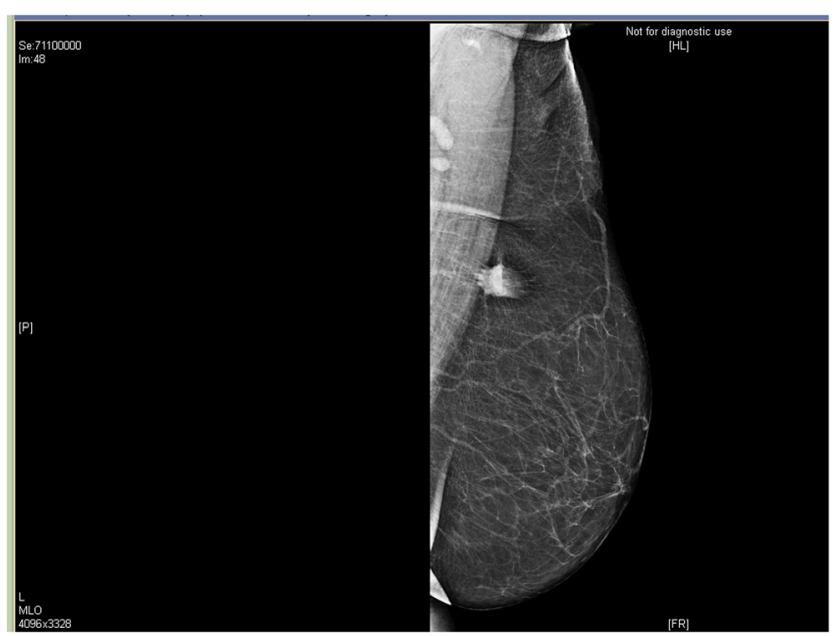

Fig. 1 MLO view showing a BIRADS V lesion in the left breast

schwannoma. Multiple granular cell tumors may seen in the context of LEOPARD syndrome, due to a mutation in the PTPN11 gene [5]. Of all cases $40 \%$ arise in the tongue. In around $5-6 \%$ of cases GCT is observed in the breast, where it can be clinically and radiologically confused with a malignant breast tumor [6].

GCT of the breast arises from intralobular breast stroma and occurs within the distribution of the cutaneous branches of the supraclavicular nerve [7, 8]. It usually presents as a solitary non tender nodule but not uncommonly is multifocal and a manifestation of multicentric disease [7]. The tumor is often found in the upper inner quadrant unlike breast cancer that is found in the upper outer quadrant [8, 9]. Since the tumor affects the innervation of the skin, contractions or shrinkage of the skin sometimes occur. These tumors most commonly occur in women between 30 to 50 years of age, ranged from 17 to 74 years with a frequency approximately 1 in 1000 breast cancers [10]. Traditional imaging techniques, including Mammogram (MMG) and ultrasound scanning,

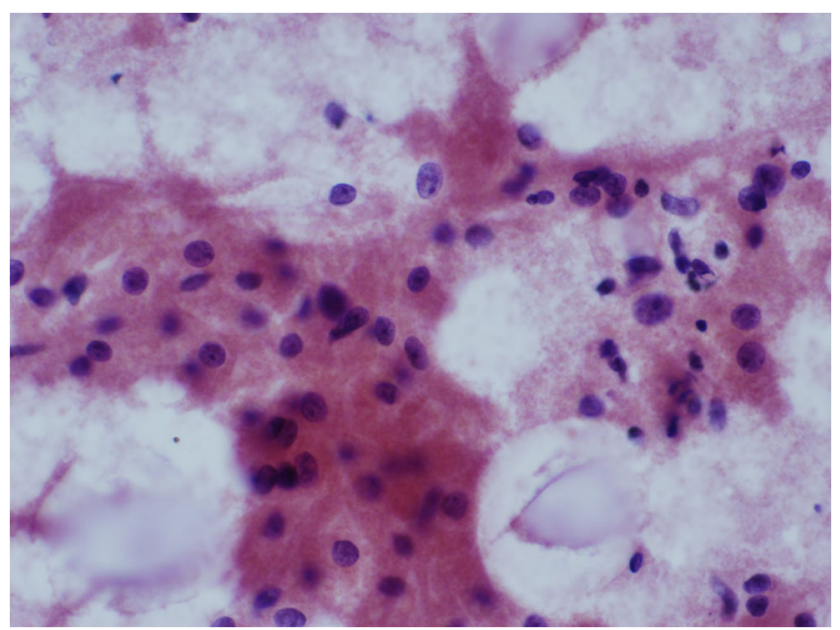

Fig. 2 Smear showing clusters of cells with abundant eosinophilic granular cytoplasm and vesicular nucleus. $(\mathrm{PAP} \times 400)$

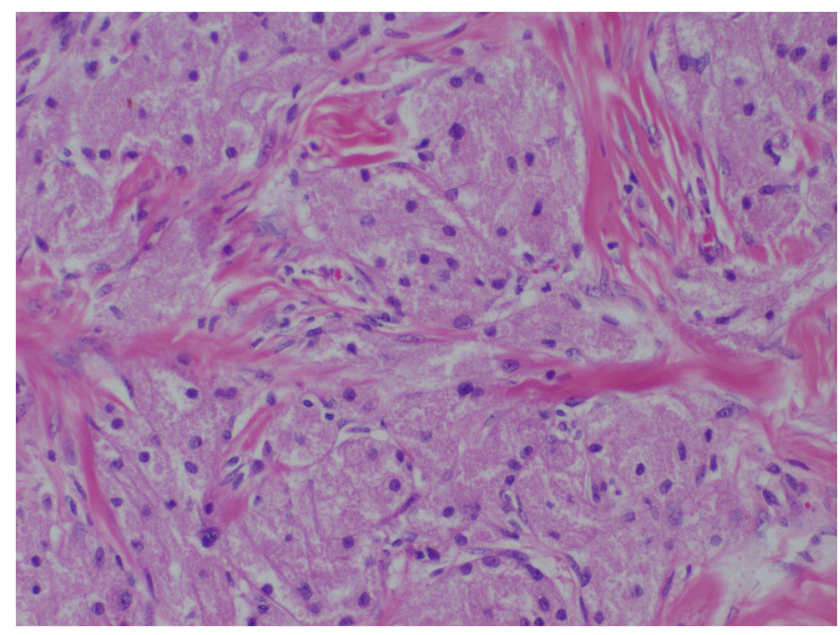

Fig. 3 Section shows a neoplasm composed of sheets of cells with abundant eosinophilic granular cytoplasm and bland vesicular nucleus. (H\&E×200)

are widely employed when investigating the mass. However in GCT the radiological findings are often indistinguishable from breast cancer. On MMG, the tumor is seen as a substantial round shaped lesion with distinct edges invading into the surrounding tissues. Irregularity, spiculations, isodensity sometimes associated with hypodense rims and heterogenicity are commonly observed, forming typical stellate mass lacking calcifications within the dense core [11]. Ultrasound usually reveals a solid mass with posterior shadowing suggestive of carcinoma [12]. Rarely the ultrasound pattern is hypoechoic with or without attenuation of the sound beam [13].

Surgery is the mainstay of treatment for GCT. Resection with adequate margins is necessary because the tumor has no capsule and is proliferation invasive [2]. However long-term risk for disease progression is low. Even the tumors excised with positive margins remain clinically stable for periods of greater than 7 years in one study [14]. Patients with positive margins remained free of tumor progression or recurrence for 89 months and patients with close margins also remained disease free during a 64-month follow-up period [14].

The most widely accepted theory has been that of a Schwann cell origin, apparently because of the positivity of the tumor for the S-100 protein [15] and the similarities exhibited in the ultrastructural features of the tumor cells and those of Schwann cells [16]. The granular appearance of the cytoplasm may be caused by accumulation of secretory granules, mitochondria, or lysosomes. Mital et al. [17] showed evidence of granule origin as infoldings of cell membrane by a process similar to myelin formation around nerves. They further argued that the subsequent phagocytosis of the infoldings by lysosomes results in the characteristic cytoplasmic granules. From a histopathologic perspective, FanburgSmith and colleagues proposed the following six criteria to determine whether a tumor is malignant or not including necrosis, spindling, vesicular nuclei with large nucleoli, 
increased mitotic activity ( $>2$ mitoses $/ 10$ high-power fields at $\times 200$ magnification), high nuclear-to-cytoplasmic ratio, and pleomorphism [18]. If none of these diagnostic criteria are met, the tumor is considered to be benign. If one or two criteria are met, the tumor is considered to be atypical, and if three or more criteria are met, the tumor is considered to be malignant. Sonobe and colleagues [19] divided malignant granular cell tumors into two groups: those that are malignant both histologically and clinically, and those that are histologically benign but clinically malignant.

The most common metastasis sites of malignant granular cell tumor are the lymph nodes, followed by the lungs. It has a tendency to spread both lymphogenously and hematogenously. Reportedly, chemotherapy and radiotherapy treatments cannot be expected to be effective, with surgical resection being the primary option [18-21].

\section{Discussion}

The clinical and the pathological characteristics of the tumor in our case report are in tandem with the published literature. Wide excision of the lesion was done and is considered as the standard treatment as per the available literature. Surgery is the mainstay of treatment of granular cell tumor of the breast and there is no role of any adjuvant therapy. The pathology of the tumor was benign, which again was consistent with the available literature.

\section{Conclusion}

Granular cell tumor is one of the rare tumors of the breast. Granular cell tumor (GCT) is a soft tissue neoplasm that originates in the nervous system. Mammographically and clinically it mimics carcinoma breast. Usually benign, wide excision with negative margins forms the mainstay of the treatment.

\section{References}

1. Abrikossoff A (1926) Uber Myome, ausgehend von der quergestreiften wilkuerlichen muskulatur. Virchows Arch Pathol Anat 260:215-233

2. Aoyama et al. (2012) Granular cell tumors: a report of six cases. World J Surg Oncol 10:204
3. Dhillon AP, Rode J (1983) Immunohistochemical studies of S100 protein and other neural characteristics expressed by granular cell tumour. Diagn Histopathol 6(1):23-28

4. Lifshitz MS, Flotte TJ, Greco MA (1984) Congenital granular cell epulis. Immunohistochemical and ultrastructural observations. Cancer 53(9): 1845-1848

5. Schrader KA, Nelson TN, De Luca A, Huntsman DG. McGillivray BC (2009) Multiple granular cell tumors are an associated feature of LEOPARD syndrome caused by mutation in PTPN11. Clin Genet 75 (2): 185-189

6. Adeniran A, Al-Ahmadie H, Mahoney MC, Robinson-Smith TM (2004) Granular cell tumor of the breast: a series of 17 cases and review of the literature. Breast J 10(6):528-531

7. Vance SF, Hudson RP (1969) Granular cell myoblastoma. Am J Pathol 52:208-211

8. Patel A, Lefemine V, Yousuf SM, Abou-Samra W (2008) Granular cell tumor of pectoral muscle mimicking breast cancer. Cases J 6:142

9. Brown AC, Audisio RA, Regitnig P (2011) Granular cell tumour of the breast. Surg Oncol 20:97-105

10. Kragel PJ, Fiorella RM, Kremer H (1995) Tumoral fibrosis and lack of circumscription in granular cell tumor of the breast. South Med J 88:1146-1148

11. Willen R, Willen H, Balldin G, Albrechtsson U (1984) Granular cell tumor of the mammary gland simulating malignancy. Virchows Arch [A] 403:391-400

12. Vos LD, Tjon A, Vroegindweij D, Vrints LW (1994) Granular cell tumor of the breast: mammographic and histologic correlation. Eur J Radiol 19:56-59

13. Gibbons D, Leitch M, Coscia J, Lindberg G, Molberg K, Ashfaq R, Saboorian MH (2000) Fine niddle aspiration cytology and histologic findings of granular cell tumor of the breast: review of 19 cases with clinical/radiological correlation. Breast J 6:27-30

14. Papalas JA, Wylie JD, Dash RC (2011) Recurrence risk and margin status in granular cell tumors of the breast: a clinicopathologic study of 13 patients. Arch Pathol Lab Med 135(7):890-895

15. Rosso R, Scelsi M, Carnevali L (2000) Granular cell traumatic neuroma: a lesion occurring in mastectomy scars. Arch Pathol Lab Med 124:709-711

16. Kommoss F, Mercer L, Schmidt RA, Talerman A (1989) Granular cell tumor of the breast mimicking carcinoma in pregnancy. Obstet Gynecol 73:898-900

17. Mithal KR, True LD (1988) Origin of granules in granular cell tumor. Intracellular myelin formation with autodigestion. Arch Pathol Lab Med 112:302-303

18. Fanburg-Smith JC, Meis-Kindblom JM, Fante R, Kindblom LG (1998) Malignant granular cell tumor of soft tissue: diagnostic criteria and clinicopathologic correlation. Am J Surg Pathol 22:779-794

19. Sonobe H, Iwata J, Furihata M, Moriki T, Ohtsuki Y (1998) Malignant granular cell tumor: report of a case and review and the literature. Pathol Res Pract 194:507-513

20. Kataoka A, Koike M, Kuranuki K, Wakayama K, Yamada S, Akasaka Y (2005) A case of malignant granular cell tumor arisen in the chest wall (in Japanese with English abstract). J Jpn Surg Assoc 66:2403-2406

21. Khansur T, Balducci L, Tavassoli M (1987) Granular cell tumor. Clinical spectrum of the benign and malignant entity. Cancer 60 : $220-222$ 